\title{
The Role of Worldview in Hermeneutics
}

\author{
Liviu Ursache
}

\begin{abstract}
There are different venues to knowledge and their importance in the process depends very much on the worldview on holds on to. I have pointed out some ways in which both modernism and postmodernism influences someone's hermeneutics, with predilection for theological hermeneutics. Even though a lot could be said about the core ideas of the two worldviews mentioned above, I am more interested, in this article, in highlighting how these could help out the interpreter in the process of knowing. In the same way, any other view of world, in future, would help the interpreter in ways former worldviews did not.

KEYWORDS: knowledge, modernism, postmodernism, hermeneutics, method, interpretation.
\end{abstract}

ne's worldview permeates all the domains of life, including that
of epistemology. ${ }^{1}$ Thus, people come to know things according
to the way they view life. There are many venues of knowledge
such as: nature, reason, experience, intuition and so on, but some
of them play a more important part than others, depending on the
worldview one holds on to. I must admit that even though I live in a
postmodern context, when it comes to knowledge I tend to appeal
more to reason than to experience.
In modernism, in the act of knowing, there is a fundamental
separation between the subject and object. Thus, one could know
whether one interpretation is adequate or not. Most modern thinkers
agree that there is such a thing as absolute truth, one that could be
traced when a certain scientific method is applied. These kind of 
methods would take one interpreter from the darkness of the lack of knowledge to the light of knowing certain universal facts. There is a clear distinction between reality and mere opinion. When it came to a text, hermeneutics is perceived as the science of interpretation in which the subject, namely the interpreter, interprets the object, namely the text. And thus, the modernists need a rigorous method in order to know the things.

The paradigm has shifted nowadays, as we moved to postmodernism, where experience plays a greater role. What is perceived as being true is only the product of the cultural context. All is subject to interpretation, even those domains that are traditionally known as scientific.Even more, in hermeneutic language could not express universal truth. That would mean that any and all language fails to describe the universal limitations of all languages. This kind of statement, therefore, discredits itself. For all its protests about the illegitimacies of "metanarratives" (worldviews), postmodernism offers a metanarrative of its own-one that cannot be true given its own precepts. ${ }^{2}$ However, a postmodern does not seem to bother with this self-contradictory principle, as if logic is not necessary in acquiring knowledge.

Even though I find faults in the postmodern worldview, I do acknowledge on one hand that almost worldviews have their weakness and on the other hand postmodernism brings its strengths in the field of interpretation. My purpose in this paper is to point out some of the negative as well as positive aspects which postmodernism brings up in the interpretation of a text. The interpreter, especially in the theological field of hermeneutics, needs to be aware of the threats that postmodernism poses, while integrating the positive results of this worldview.

\section{The Uncertainty of What We Perceive to Know}

Wilhelm Dilthey was the first one to give hermeneutics an "ontological turn." ${ }^{3}$ His contribution to hermeneutics consists in relating it with human sciences. For Dilthey, interpretation means the unification

of subject and object in a single historical act of understanding. The 
reader is in a more privileged position than the author because he can both deal with the mind of the author and bring more technics in interpretation. It follows that he could create meanings that could be more profound than what the authors might have created. ${ }^{4}$

The text makes sense only when the interpreters approach it and could find significance for life and thus limiting the meaning of the text to what corresponds to personal experience. The concept of "new hermeneutic" turns its attention to how could the ancient texts communicate with power and freshness for today. It studies everything though the lens of contemporaneity. Since the reality is fluctuating, the meaning of a text could neither be a fixed one nor authoritative. The stress in on the interpreter's creative capacity to deal with a text, since they are not limited by the rules of the traditional and dogmatic hermeneutic.

The characteristic of this hermeneutic is the weakening of the distinction between subject and object. The interpreter brings a whole baggage of pre-understanding to the text. "Even the questions that the interpreter is asking (or fails to ask) reflect the limitations determined by that baggage. These pre-understandings would determine the answers that come from the text and also the way they are interpreted." 5

One caveat of postmodern hermeneutics is the uncertainty of knowledge. We cannot know what we need to know because there are many factors that can thwart the understanding. For one the text may say something while for another the meaning could be a totally different thing and there is no way to check whose interpretation is more adequate. Knowledge is not possible anymore as it used to be for the modernists. The reason why for this state of things lies in the reaction of postmodern to the modern assertion of truth. Thus, statements about religious claims, moral principles and even about scientific facts cannot refer to objective states of affairs. ${ }^{6}$

Postmodern epistemology encourages us to acknowledge that there is no ground for foundationalism, there is no room for certainty. There is always the aspect of human's error. Also, the method applied to discover the truth is not set, it depends on the context. Language is subject to local communities and it cannot move beyond its own context and refer to realities outside itself. Words have significance 
through their role in the certain contexts and not by their relation to some timeless entities, with the categories understood by both philosophers and common people.

Truth could not be universal, even when we talk about scientific discoveries. This is why feelings can be a source of knowledge. The interpreters are never passive recipients of either data or experiences unless one has to ignore the complex horizons of human beings. Also, there is no way one can escape his presuppositions, preunderstandings or traditions, things one interpreter is always bringing to the text. That brings relativism in the act of knowing.

One interpreter cannot come to the objective truth of the text. Simply, one has no access to what the text really says. There is only one truth-that which is interpreted. Meaning has nothing to do with what the author has to say but with what the interpreter sees or understands. This perspective is known as "new critique" 7 and holds that one written, the text is an independent entity and is on its own. The author does not matter anymore because the meaning of the text is up to the interpreter or, rather, to the worldview that one holds on to. The new hermeneutics presupposes that the interpreter dialogues with the text in order to connect to an historical context and a language that are different. He needs to find the original intent so that it could be contextualized and, in the same time, to have the same impact for nowadays. When the text influences somebody's life, then it becomes truth for that person. ${ }^{8}$

Thus, there needs to be a dialogue between the subject and the object so that the questions that are being asked and answered determine him to see things differently; this interaction determines a process through which the hermeneutical circle is being shaped. Some authors prefer the phrase "hermeneutical spiral," ${ }^{9}$ in order to show that the interpreter is not taking a vicious circle. So, as the interpreter interacts more and more with the text and his understanding aligns with that of the author.

Even the distinction between the subject and the object of hermeneutic is not total, the interpreter could always ask what the intention of the author was. The role of this hermeneutics is that of emphasizing the distinction between the understanding and the 
text itself. This teaches us that we are limited and that we need to be aware of our pre-understandings when dealing with the text.

\section{The Added Knowledge an Interpreter Brings to the Text}

Postmodernism builds up on the weaknesses of the modern worldview. The latter stresses out that absolute certainty is possible and that ultimately, science reveals truth. The former, however, considers that the interpreter does not need to have as his goal perfect objectivity but rather objectivity within the limits of some essential presuppositions. This is a challenge, but it is the call of the interpreter. Thus, interpretation is text oriented rather than author oriented. Even though the relationship speaker-listener is lost in the text, the latter could share the world of the text. So, while the objectivity of the goal of the author is always a theoretical construction, the referent world, created by the author includes the reader. ${ }^{10}$

The text in not linear, as it is the case when one interprets the text with the authorial intention lens, but is multidimensional, as it does not offer itself to reading on a single level but on more levels in the same time to a historical community that has heterogeneous goals. Thus, the reader is included in the text; he is part of the text. Paul Ricoeur said: "just as a hermeneutic that stresses out the intention of the author tends to give a statute of unicity for the sense of a text, as it tends to reduce the meaning of the author to a unique intention, in the same way a hermeneutic that is interested in the history of reception would take into account the irreducible plurivocity of the text."11

Thus, Ricoeur believes that when the interpreter studies

a text he interprets himself. A kind of mutual choice takes place between the text and the interpreter and this process in known as "hermeneutical circle". This is not a vicious only when the studied text is considered as sacred and the interpreter refers to an authority. Thus, the text and the interpreter could not change places, which in the words of Ricoeur, show a difference of "altitude". ${ }^{12}$ 
While denying the objectivity of interpretation, which theological hermeneutics would always hold against because of its subsequent relativism, the merit of postmodernism lies in the recognition of the human factor in acquiring the knowledge. Two things are worth underlining when taking into consideration the input of the interpreter: the tradition of the text and its relationship with the living community.

For the first aspect, the wise emperor Solomon once said: "nothing new under the sun."13 Applied in the area of hermeneutics, it means there is no singular interpretation. Anything that is being said today, all interpretations, has been also done in the past too. Thus, the interpreter is dependent on the work of his forerunners, even though there are some naïve interpreters, who believe they could interpret a text without help from others. Don Carson believes that the "exegesis could never be done in a vacuum." ${ }^{14}$ It is absurd to believe that one's background does not influence his exegesis. We definitely could not establish a certain pattern for the influences, but one can be sure that his community irrevocably determines the way he views and interprets the texts.

Also, the interpretation of a text could not be separated from the contemporary community. The third element of the interpretative triangle is the reader. Ricoeur said: "in the end, the text exists because of a community, to be used in a community and to shape that community. If we consider that the relation with the author is the background of the text, then the relation with the reader is the foreground. In this case we firmly consider that foreground is more important than the background."15

The interpreter could not ignore the world he lives in. One would always compare the results of his interpretation with the reality of the community he lives in. In this way, a symbiosis is created between the world of the text and that of the community. Ricoeur believes that "a text separated from its ties with the community is as good as a corpse."16 This principle could be also observed in the Jewish tradition. In Judaism there is a written Torah but also one that is orally transmitted. There is no break between them as the latter is considered an extension of the former, of its vitality and capacity of filling the temporal horizon. 
One, definitely, comes to know things when the text in analyzed against the backdrop of contemporaneity. Most likely this is what Hirsch had in mind when he distinguished between meaning and significance. ${ }^{17}$

\section{Conclusions}

This article does not seek to respond to either modernism or postmodernism but rather to point out some of their contribution to epistemology. Chronologically, the postmodern worldview follows the modern one and today there are some voices that speak of a post-postmodern view. This means that there is always movement in terms of how people see life and the interpreter of a text needs to understand the times in order to see how knowledge is acquired.

For a theological interpret knowledge is possible because the truth is out there, in the text, and could be discovered through adequate methods of biblical studies. In the same time, however, there needs to be humbleness from the interpreter's part in recognizing his/her limits due to the human condition. That helps the interpreter to appreciate the value of the community.

Through this article I wanted to show that there is always bad and good news as to the emphasis people give to different venues of knowing, of course within certain limits. As humans we are limited and at times we emphasize on aspect of knowing, just as moderns did with the scientific methods, and later we swing the pendulum on the very opposite because we missed the value of community and experience in the process of knowing.

I like the perspective of Paul, the apostle, on the future of knowledge. He writes to the Corinthians, to people whom interest was turned to knowledge. He tells his readers that on this side of heaven they can only know in part but on the other side they would fully know: "For now we see in a mirror dimly, but then face to face; now I know in part, but then I will know fully just as I also have been fully known."18 


\section{NOTES}

${ }^{1}$ Ioan-Gheorghe Rotaru, Istoria filosofiei, de la începuturi până la Renaştere (Cluj-Napoca: Presa Universitară Clujeană, 2005), 34-7.

2 D.A. Carson, The Dangers and Delights of Postmodernism, Modern Reformation (Cf. http://www.modernreformation.org/default.php?page=articl edisplay\&var2=281 Last accessed on April 15, 2016.)

3 Ramberg, Bjørn and Gjesdal, Kristin, Hermeneutics, The Stanford Encyclopedia of Philosophy (Summer 2013 Edition), Edward N. Zalta (ed.), (Cf. http://plato.stanford.edu/archives/sum2013/entries/hermeneutics/ Last accessed on April 20, 2015.)

${ }^{4}$ Grant R. Osborne, The hermeneutical spiral: A comprehensive introduction to biblical interpretation, (Downers Grove, IL: InterVarsity Press), 468.

${ }^{5}$ Don A. Carson, Exegetical Fallacies, $2^{\text {nd }}$ edition, (Grand Rapids, MI:Baker Books, 1996), 126.

${ }^{6}$ Douglas Groothuis, Truth Decay, (Downers Grove, IL: InterVarsity Press, 2000), Chapter 2.

${ }^{7}$ John Stonestreet, Understanding the Times, gen. ed. David Nobel, Student Manual, (Manitou Springs, CO: Summit Press, 2006), 97.

${ }^{8}$ Anthony C. Thiselton, "A New Hermeneutic," New Testament Interpretation: Essays on Principles and Methods, ed. I. Howard Marshall (Grand Rapids, MI: Eerdmans, 1977), 308-33.

${ }^{9}$ Grant R Osborne, The hermeneutical spiral: A comprehensive introduction to biblical interpretation. This author believes that hermeneutics is a spiral from text to context-a move between the horizon of the text to that of the reader and which draws closer to the intention of the text and its significance for today. Osborne develops his argument in each of the three sections of his books: general hermeneutics (grammar, semantics, syntax and context), genres and applied hermeneutics.

${ }^{10}$ Paul Ricoeur, The Hermeneutical Function of Distanciation, (Philosophy Today 17, 1973), 135-41.

${ }^{11}$ La Cocque, Andre și Paul Ricoeur, Cum să în国elegem Biblia, 6.

${ }^{12}$ Ibidem.

${ }^{13}$ Bible, Ecclesiastes 1:9.New American Standard Bible: (LaHabra, CA: The Lockman Foundation, 1995).

${ }^{14}$ Don A.Carson, Unity and Diversity in the New Testament: the Possibility of the Systematic Theology, 92.

15 James Sire, The Universe Next Door, 4th ed. (Downers Grove, IL: InterVarsity Press, 2004), 237.

${ }^{16}$ La Cocque, Andre și Paul Ricoeur, Cum să în lelegem Biblia, (Iași, Romania: Polirom, 2000), 7.

${ }^{17}$ Hirch, Validity in Interpretation, (Chicago, IL: University of Chicago Press, 1976).

${ }^{18}$ Bible, 1 Co 13:12. New American Standard Bible: (LaHabra, CA: The Lockman Foundation, 1995). 
BIBLIOGRAPHY

*** New American Standard Bible: (LaHabra, CA: The Lockman Foundation, 1995).

Carson, A. Don, The Dangers and Delights of Postmodernism, Modern Reformation (Cf. http://www.modernreformation.org/default.php?page=articl edisplay\&var2=281 Last accessed on April 15, 2016.)

Exegetical Fallacies, $2^{\text {nd }}$ edition, (Grand Rapids, MI: Baker Books, 1996).

The Gagging of God, (Grand Michigan, MI: Zondervan, 1996).

Unity and Diversity in the New Testament: the Possibility of the Systematic Theology, 92.

Groothuis,Douglas Truth Decay, (Downers Grove, IL: InterVarsity Press, 2000).

Hirch, E. D., Validity in Interpretation, (Chicago, IL: University of Chicago Press, 1976).

La Cocque, Andre și Paul Ricoeur, Cum să în䀏elegem Biblia, (Iași, Romania: Polirom, 2000).

Osborne,R. Grant The hermeneutical spiral: A comprehensive introduction to biblical interpretation, (Downers Grove, IL: InterVarsity Press).

Ramberg, Bjørn and Gjesdal, Kristin, Hermeneutics, The Stanford Encyclopedia of Philosophy (Summer 2013 Edition), Edward N. Zalta (ed.), (Cf. http://plato.stanford.edu/archives/sum2013/entries/hermeneutics/ Last accessed on April 20, 2015.)

Ricoeur,Paul,The Hermeneutical Function of Distanciation, (Philosophy Today 17, 1973), 135-41.

Rotaru, Ioan-Gheorghe, Istoria filosofiei, de la începuturi până la Renaştere, (Cluj-Napoca, Romania: Presa Universitară Clujeană, 2005).

Sire, James, The Universe Next Door, 4th ed. (Downers Grove, IL: InterVarsity Press, 2004).

Stonestreet, John,Understanding the Times, gen. ed. David Nobel, Student Manual,(Manitou Springs, CO: Summit Press, 2006).

Thiselton, C. Anthony, "A New Hermeneutic," New Testament Interpretation: Essays on Principles and Methods, ed. I. Howard Marshall (Grand Rapids, MI: Eerdmans, 1977). 